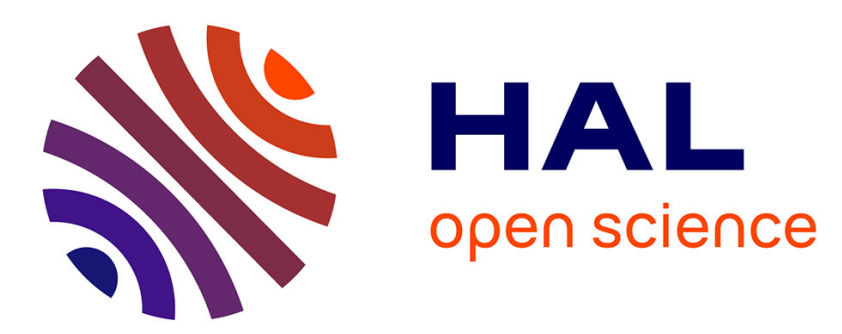

\title{
Controls on detrital sedimentation in the Cariaco Basin during the last climatic cycle: insight from clay minerals
}

A. Riboulleau, Viviane Bout-roumazeilles, N. Tribovillard

\section{To cite this version:}

A. Riboulleau, Viviane Bout-roumazeilles, N. Tribovillard. Controls on detrital sedimentation in the Cariaco Basin during the last climatic cycle: insight from clay minerals. Quaternary Science Reviews, 2014, 94, pp.62-73. 10.1016/j.quascirev.2014.04.023 . hal-03282860

\section{HAL Id: hal-03282860 \\ https://hal.science/hal-03282860}

Submitted on 9 Jul 2021

HAL is a multi-disciplinary open access archive for the deposit and dissemination of scientific research documents, whether they are published or not. The documents may come from teaching and research institutions in France or abroad, or from public or private research centers.
L'archive ouverte pluridisciplinaire HAL, est destinée au dépôt et à la diffusion de documents scientifiques de niveau recherche, publiés ou non, émanant des établissements d'enseignement et de recherche français ou étrangers, des laboratoires publics ou privés. 
1 Controls on detrital sedimentation in the Cariaco Basin during the last

2 climatic cycle: insight from clay minerals

4 A. Riboulleau*, V. Bout-Roumazeilles, N. Tribovillard

5 Université Lille 1, Laboratoire Géosystèmes, UMR 8217 CNRS, Bâtiment SN5, 59655

6 Villeneuve d'Ascq Cedex, France

7 * Corresponding author. Tel.: +33 3204341 10; fax: +33 320434910 .

8 E-mail address: armelle.riboulleau@univ-lille1.fr (A. Riboulleau).

Keywords: Cariaco Basin - Clay minerals - ITCZ - Eemian - Younger Dryas - Detrital 11 sedimentation

\section{Abstract}

A high resolution analysis of the clay mineral content of sediments of the Cariaco Basin spanning the last climatic cycle was performed in order to determine how the detrital sedimentation in the basin records climatic oscillations at various timescales. At the scale of glacial interglacial cycles, the clay mineral content records changes in the geographic origin of the detrital supply, from a dominantly kaolinite- and smectite-rich southern source during glacial to a more illite-rich northerly source during interglacials. Though possibly influenced by eustatic variations, these changes mostly reflect the latitudinal fluctuations of the intertropical convergence zone (ITCZ). The Eemian shows an increased contribution from the northern source compared to the Holocene. During MIS3, seasonality modulates the effect of ITCZ position and leads to increased smectite contribution. Fluctuations of the smectite and kaolinite contents during Dansgaard/Oeschger cycles reflect changes of runoff intensity. Enhanced supplies in kaolinite during Heinrich-like events and stadials also suggest remobilizations of sediments deposited on the Unare platform resulting from rapid sea-level variations. The Younger Dryas is characterized by a significantly different clay mineral association reflecting a drastic modification of terrigenous supply. An eolian contribution would explain this peculiar mineralogy, although local contributions cannot be ruled out. A similar event is noted at the MIS6-5 transition pointing for the occurrence of a Younger Dryas

31 like episode during Termination II. 
Tropics are a major source of methane and water vapor to the atmosphere. Through the emission of these greenhouse gases and of latent heat, tropics play a key role in the equilibration of the climate system (Ruddiman, 2001; Chiang, 2009). For this reason, tropics have also been important in the propagation of past climatic variations (Lea et al., 2000; Hoerling et al., 2001; Ivanochko et al., 2005; Broecker and Putnam, 2013). One of the key aspects in tropical paleoclimatology is the location of the intertropical convergence zone (ITCZ). It is well documented that the yearly latitudinal fluctuations of the ITCZ are superimposed over longer term fluctuations that accompanied larger scale climatic evolutions from the orbital glacial/interglacial scale, to the pluriannual El Niño Southern oscillations (e.g., deMenocal et al., 2000b; Wang et al., 2004; Fleitmann et al., 2007; Hessler et al., 2010). At a given date, location of the ITCZ results from the influence of insolation, landmass distribution, ice cover and sea surface temperature (SST) distribution, explaining its sensitivity to global climatic fluctuations (Chiang et al., 2002, 2003; Chiang and Bitz, 2005). Conversely, the location of the ITCZ has an influence on tropical water budget and can influence global climate through feedback effects and potential modification of thermohaline circulation (Romanova et al., 2004; Braconnot et al., 2007; Leduc et al., 2007).

Determining past position of the ITCZ using the geological record is difficult. Most studies are based on proxies that indirectly document changes in rainfall or wind intensities, allowing to determine whether the study site was located under or beyond the influence of ITCZ rainbelt or trade winds (deMenocal et al., 2000b; Haug et al., 2001; Wang et al., 2001; Lachniet et al., 2004, 2009; Jullien et al., 2007; Placzek et al., 2013). The presence (or absence) of rain in one place mainly documents the position of the summer ITCZ at the study site. Seasonality and duration of the humid season, which are key parameters for rainfall distribution and water budget, are however rarely documented. The comparison of records from different latitudes and in particular from both hemispheres (Wang et al., 2004; Fleitmann et al., 2007; Lachniet et al., 2009; Arbuszewski et al., 2013) can help trace latitudinal fluctuations and seasonality, however such an approach needs to compare extremely well dated records.

The Cariaco Basin located off Venezuelan coasts is directly influenced by latitudinal variations of the ITCZ. During Northern Hemisphere winter, strong trade winds due to the southern position of the ITCZ lead to arid conditions on land and upwelling of nutrient-rich water in the basin. From December to April, the sedimentation is therefore dominated by biogenic opal, carbonate and organic matter (Muller-Karger et al., 2001; Martinez et al., 2007). During Northern Hemisphere summer, the ITCZ lies above the Cariaco Basin. The 
decrease of trade-wind intensity leads to significant weakening of the upwelling and important rainfall leads to a sedimentation dominated by clayey detrital material from June to October (Muller-Karger et al., 2001; Martinez et al., 2007). Anoxia of thewater column below $300 \mathrm{~m}$ allows the preservation of these seasonal changes as varves: a light colored lamina deposited during the upwelling season alternates with a dark colored lamina deposited during the rainy season (Peterson et al., 1991; Hughen et al., 1996a). Due to their strong dependence on the ITCZ location and finely preserved record, the Cariaco Basin sediments have been extensively studied during the last decades. In particular, the sedimentary record of latitudinal fluctuations of the ITCZ on different timescales has been investigated using different methods: bulk geochemistry (Peterson et al., 2000a; Haug et al., 2001; Peterson and Haug, 2006), sediment color (Hughen et al., 1996b; Deplazes et al., 2013), foraminifer content (Black et al., 1999), SST paleothermometry based on foraminifers (Lea et al., 2003) and alkenones (Goni et al., 2006), or palynology (González et al., 2008a, 2008b). Several studies however also document that sea level variations at different timescales exerted a control on sedimentation in the Cariaco Basin (Peterson et al., 1991; Clayton et al., 1999; Yarincik et al., 2000; González and Dupont, 2009), so that deconvolution of the eustatic and climatic signals may be difficult.

The present paper describes the analysis of the clay mineral content of the sediments from the Cariaco Basin spanning the entire climatic cycle. Because clay minerals mostly originate from the weathering of emerged lands and are transported to sedimentary basins, their study allows tracing numerous different processes such as continental weathering (Chamley, 1989), strength and route of oceanic currents (Fagel et al., 1996, 2001; BoutRoumazeilles et al., 1999), rainfall patterns (Montero-Serrano et al., 2009, 2011), or eolian processes (Jullien et al., 2007) which are key parameters for understanding past variations of the climate. In the Cariaco Basin sediments, the clay mineral content is used in order to better constrain temporal changes of the detrital flux in relation to eustatic and climatic fluctuations.

\section{Material and methods}

\subsection{Studied material}

The present study is based on sediment from the IMAGES Program core MD03-2625 $\left(10^{\circ} 40.650 \mathrm{~N}, 64^{\circ} 58.240 \mathrm{~W}\right.$, water depth $\left.847 \mathrm{~m}\right)$ recovered during the PICASSO cruise $(\mathrm{R} / \mathrm{V}$ Marion Dufresne; Laj and Shipboard Scientific Party, 2004) and Ocean Drilling Program (ODP) site 1002 (1042.360 N, 65¹0.160 W; water depth, 893 m; Shipboard Scientific Party, 1997). Sediment from holes $1002 \mathrm{D}$ and $\mathrm{E}$ were used in order to get the most complete record 
102 (Hughen et al., 2004). Both coring sites are located on the central saddle of the Cariaco Basin, 103 however core MD03-2625 is located on its eastern side while ODP site 1002 is located on its 104 western side (Fig. 1). The presented data correspond to a composite of the two cores: MD032625 for the interval $0 \mathrm{e} 11.66 \mathrm{ka}$ and ODP 1002 for the interval $11.60 \mathrm{e} 132.55 \mathrm{ka}$. Continuity of the record was ascertained by the colorimetric correlation of the different cores (see

107 below).

\subsection{Age model}

The ODP depth scale does not allow a perfect correlation of the different ODP 1002 holes. A new composite depth scale was therefore established by correlating the parameters $\mathrm{L}^{*}$ (sediment lightness) and the magnetic susceptibility of cores 1002C, 1002D and 1002E

113 (Table S1; Fig. S1). The age model was then derived from the age models established by

114 Hughen et al. (2006) and Drenzek (2007), using the new composite depth scale. Rapidly, for 115 sediment younger than $75 \mathrm{ka}$ (Hughen et al., 2006), the age model is based on the correlation 116 of core $1002 \mathrm{D}$ sediment reflectance with $230 \mathrm{Th}$-dated stalagmite $\delta^{18} \mathrm{O}$ records from Hulu 117 Cave, China (Wang et al., 2001). For sediment older than $75 \mathrm{ka}$, the age model is based on a correlation of the oxygen isotopic composition of planktonic foraminifer Globigerinoides ruber shells collected from core 1002D (Drenzek, 2007), with the global benthic foraminiferal $\delta^{18} \mathrm{O}$ stack of Lisiecki and Raymo (2005).

For core MD03-2625, the age model was determined by correlating the colorimetric parameter $\mathrm{a}^{*}$, describing sediment color from red to green, acquired on board (Laj and Shipboard Scientific Party, 2004) with gray-scale data of core PL07-56 PC (Hughen et al., 1996b), using a more recent age model (Hughen et al., 2000; Table S2; Fig. S2). For the correlation, core PL07-56 PC was preferred over core ODP 1002, because it is located closer to core MD03-2625 and is very well dated (Hughen et al., 1996b, 2000). The software used for the correlation was AnalySeries (Paillard et al., 1996). The obtained ages are calibrated years before present (yr cal. B.P.). The sedimentation rate thus obtained for the two cores varies between 0.11 and $1.2 \mathrm{~mm} / \mathrm{yr}$ with an average value of $0.37 \mathrm{~mm} / \mathrm{yr}$ for the studied interval.

\subsection{Methods}

The sediment was systematically sampled with a $10 \mathrm{~cm}$ step for the entire climatic cycle, representing a total set of 480 samples (54 for MD03-2625 and 426 for ODP 1002). This corresponds to an average sampling interval of $212 \mathrm{yr}$ for MD03-2625 and $286 \mathrm{yr}$ for 
136 ODP 1002. Clay mineral associations were studied using X-ray diffraction following the 137 protocol of Bout-Roumazeilles et al. (1999). "Clay minerals" here refer to the major 138 phyllosilicate minerals within the clay-size fraction $(<2-\mathrm{mm}$ particles $)$. All samples were first decalcified with $0.2 \mathrm{M} \mathrm{HCl}$. Defloculation of clays was achieved by successive washing with distilled water. The clay-size fraction was separated by settling according to Stokes's law, concentrated by centrifugation, and oriented by wet smearing on glass slides. X-ray diagrams were obtained using a Philips PW 1749 diffractometer with CuKa radiation and a Ni filter. A tube voltage of $40 \mathrm{kV}$ and a tube current of $25 \mathrm{~mA}$ were used. Three X-ray diagrams were performed: air-dried sample (normal run), ethylene glycol vapor saturation for $12 \mathrm{~h}$ (glycol run) and heating at $490{ }^{\circ} \mathrm{C}$ during $2 \mathrm{~h}$ (heating run). The goniometer scanned from $2.49^{\circ}$ to $32.49^{\circ} 2$ theta for normal and glycol run and from $2.49^{\circ}$ to $14.5^{\circ} 2$ theta for heating run. Each clay mineral is characterized by its basal layer plus interlayer interval (d) as revealed by XRD analysis (Brown and Brindley, 1980). Expandable mineral are characterized by a peak at $14 \AA$, which expands to $15-17 \AA$ after ethylene glycol saturation and retracts down to $10 \AA$ after heating. Distinction between smectite (S) and illite-smectite mixed-layer minerals (IS) was based on the position of the main peak after glycol saturation ( $17 \AA$ and $15 \AA$ respectively) and on the presence of "superstructure" at $29 \AA$ for the air-dried sample, expanding at $30 \AA$ after glycol saturation, which characterizes the presence of regular illite-smectite mixed-layer minerals. Illite (I) is characterized by peaks at $10 \AA, 5 \AA$ and $3.33 \AA$, which remain unchanged on the three tests. Chlorite $(\mathrm{C})$ is characterized by peaks at $14 \AA, 7 \AA, 4.75 \AA$ and $3.53 \AA$ on the three runs. Kaolinite $(\mathrm{K})$ is characterized by peaks at $7 \AA$ and $3.58 \AA$ on the normal and glycol runs. Both peaks disappear or are strongly reduced after heating. To distinguish kaolinite from chlorite, the portion of the spectrum containing the basal peaks of kaolinite and chlorite around $3.55 \AA$ is step-scanned in a high-resolution mode following standard procedures described in detail by Petschick et al. (1996). Semi-quantitative estimation of clay-mineral abundance is based on peak areas $[17 \AA$ (smectite) $+15 \AA$ (illite-smectite mixed-layers) $+10 \AA$ (illite) $+7.2 \AA$ (kaolinite and chlorite) $]$ as measured on the ethylene glycol saturated test using MacDiff $^{\circledR} 4.2 .5$ software (Petschick, 2002) summed to $100 \%$. The error on the reproducibility 164 of measurements is estimated to be $\pm 5 \%$ for each clay mineral. The illite crystallinity and the 165 Esquevin index were measured on the XRD diagrams. The illite crystallinity (in ${ }^{\circ} 2$ theta) corresponds to the full width at half maximum (FWHM) measured on the illite peak at $10 \AA$ (Chamley, 1989). The illite crystallinity, or Kübler index, is inversely proportional to the metamorphism degree: a high index indicates very low-to-low metamorphism whereas low values reflect a high metamorphism. A low signal-to-noise ratio did not allow to correctly 
determine the Kübler index for core MD03-2625. The Esquevin index or chemical weathering index (Esquevin, 1969) corresponds to the ratio between the illite intensity measured at $5 \AA$ and at $10 \AA$ and is used to evaluate the chemical composition of illite (Al-rich versus Fe/Mgrich).

Grain-size analysis was carried out on the carbonate-free fraction of the sediment using a Malvern Mastersizer 2000 laser diffractometer, which has a detection range of $0.02 \mathrm{e} 2000 \mathrm{~mm}$. Defloculation of the samples was done by successive washing with distilled water after decarbonatation of the sediments with $0.2 \mathrm{M} \mathrm{HCl}$. Sample quantity was adjusted in order to obtain a laser beam obscuration between 12 and $15 \%$. We used a refractive index (RI) value of 1.544 (quartz) and an absorption value of 0.05 . The distribution parameter reported here is the mean grain size $(\mathrm{mm})$. Relative uncertainty on this value $(2 \mathrm{~s})$ is $4 \mathrm{e} 6 \%$ (Sperazza et al., 2004).

\section{Results}

On average, the clay minerals assemblage comprises, in decreasing abundance kaolinite $(\mathrm{K}, 33 \%)$, smectite $(\mathrm{S}, 25 \%)$, illite (I, 21\%), chlorite (C, 14\%) and mixed layers illite-smectite (IS, 7\%). The clay mineral assemblages display rather important variations at orbital timescale. Smectite and illite contents are strongly anticorrelated, but the anticorrelation is less marked between smectite and (I + IS) (Table S3). The Last Glacial period (MIS 2e4) is characterized by the lowest illite contents $(<20 \%)$ and high smectite contentsw28\% (Fig. 2; Table 1). The highest smectite content (30\%) is observed during MIS3. Conversely MIS 5e shows high illite (27\%) and the lowest smectite contents $(17 \%)$ (Fig. 2; Table 1). MIS5a-tod are slightly enriched in kaolinite ( $>35 \%)$ when compared with the whole record average values. Relatively low smectite contents (w20\%) associated to higher-than-average mixed layer (>10\%) characterize MIS1 (Fig. 2). They are particularly abundant (17\%) at the beginning of MIS1: Younger Dryas in hole ODP 1002, end of Younger Dryas to Preboreal in core MD03-2625 (Fig. 2; Table 1). Kaolinite content shows marked variation during terminations: high values at the end of MIS6 and MIS2 are followed by low values at the MIS6-5 transition and Younger Dryas (Fig. 2). High kaolinite contents also characterize the end of MIS5b, 5a and 4 (Fig. 2). Chlorite only shows minor variations with a peculiar enrichment during the Bølling/Allerød (B/A) period (Fig. 2). Compared to the global variations of benthic $\delta^{18} \mathrm{O}$ (Lisiecki and Raymo, 2005) and to $\delta^{18} \mathrm{O}$ values of G. bulloides within the sediment (Drenzek, 2007), the smectite and illite content shows a marked positive/negative correlation with $\delta^{18} \mathrm{O}$, whereas chlorite and kaolinite do not show any clear 
correlation with $\delta^{18} \mathrm{O}$ (Fig. 2, Table S4).

When clay minerals variations between 20 and $70 \mathrm{ka}$ are observed into more detail, the smectite content tends to be higher during the long ones (GIS 8, 10 and 14e13), and lower during low latitude equivalents of Heinrich events (Fig. 3), whereas the kaolinite content generally shows high values at the beginning of Heinrich-like events (Fig. 3). Smectite and kaolinite are negatively correlated on this restricted portion (Fig. 3; Table S3).

For most samples, grain size distribution is mono-modal. The mean grain size is close to $10 \mathrm{~mm}$ and silts (grains $<63 \mathrm{~mm}$ ) represent the dominant fraction $(>90 \%)$ of the decarbonated sediment. The mean grain size only shows minor variations and is not significantly correlated with benthic or planktonic $\delta^{18} \mathrm{O}$ values (Fig. 4, Table S4). Maximum values are observed during MIS3 and MIS1. For MIS1, the high values can be related to the presence of diatoms in the sediment. Minimum values of the mean grain size, reflecting an increased contribution of clay-sized material are observed during MIS4 and MIS2. Drops in the mean grain size of the sediment also are often coeval with Heinrich-like and cold events of MIS3 and MIS5 (Fig. 4).

\section{Discussion}

\subsection{Evolution of clay minerals at the glacial-interglacial timescale}

A recent study of the distribution of clay minerals on the shelf surrounding the Cariaco Basin proposed the use of $\mathrm{I} /(\mathrm{C}+\mathrm{K})$ and $\mathrm{I} / \mathrm{S}$ ratios to distinguish detrital sources (BoutRoumazeilles et al., 2013). In the $\mathrm{I} / \mathrm{S}$ vs $\mathrm{I} /(\mathrm{C}+\mathrm{K})$ diagram, our new data mainly plot in a mixing triangle between the Unare, Tuy, and Neveri rivers (Fig. 5). The clay minerals composition of most intervals can thus be modeled by a simple mixing between these sources (Table 2). Interglacials (Holocene and MIS5) show a higher contribution from the Tuy and Neveri rivers (Table 2). This interpretation is supported by the variations of Kübler and Esquevin indexes (Fig. 4). The Tuy and Neveri Rivers transport illite deriving from highly to slightly metamorphosed rocks and are hence characterized by a higher crystallinity than the illite delivered by the Unare River, deriving from Cenozoic and Mesozoic sedimentary formations (Bout- Roumazeilles et al., 2013). Our data indicate that illite minerals are generally well crystallized and less altered during interglacials than during glacials (Fig. 4), supporting an increased contribution from the Tuy and Neveri rivers during interglacials. By contrast, Last Glacial samples (MIS2 to 4) plot close to the Unare River endmember, though MIS3 data shows a slightly more dispersed pattern (Fig. 5). To summarize, the variations of the clay mineral assemblage at the glacial-interglacial timescale primarily result from a 
change in the location of the detrital sources: during glacials the sediment almost exclusively originate from a southern source (Unare River) while an additional contribution from northern sources (Tuy and Neveri rivers) occurs during interglacials.

Clayton et al. (1999) interpreted the anticorrelation between smectite and illite, and their link with the global benthic $\delta^{18} \mathrm{O}$, as reflecting eustatically-driven changes in the respective contribution of smectite-rich local rivers vs the allochthonous supply from the illite-rich Orinoco-Amazon system. However Bout-Roumazeilles et al. (2013) evidenced that sediments from the Orinoco delta are rather enriched in smectite, which led to revise this interpretation. From the distribution of clay minerals on the shelf surrounding the Cariaco Basin, and consistent with geochemical data (Martinez et al., 2010), Bout-Roumazeilles et al. (2013) proposed that the mineralogical variations observed by Clayton et al. (1999) reflect a change in the respective contribution of local rivers only.

Even considering local supplies only, the observed provenance changes could still be of eustatic origin. High sea-level stand during interglacials may promote efficient offshore mixing of the various detrital sources whereas during glacials, the mouth of the Unare river is very close to the basin edge favoring specific supply from the Unare river to the deep basin. Changes in river erosion/deposition in relation to sea-level variations may also be involved. Rivers are highly erosive during sea-level falls, leading to high sediment delivery to the basin (e.g., Schumm, 1993). While metamorphic rocks in the Northern coastal range of Venezuela do not constitute a highly erodible substrate, the Mesozoic to Tertiary sedimentary rocks present in the Unare drainage basin represent softer material. Important sediment delivery from the Unare River compared to the Tuy River can therefore be expected during glacial sealevel falls. Conversely, during and shortly after sea level rise, sedimentation in the previously incised valleys leads to sediment starving in the basin (Schumm, 1993). The sediment flux from the Unare River could therefore be reduced during interglacial highstands, allowing the sediments derived from the northern detrital sources to be less diluted. The anticorrelation between the terrigenous contribution (Yarincik et al., 2000) and the illite-to-smectite ratio (Fig. S3) used as a tracer of the southern versus northern contributions gives some support to these mechanisms. However, the highest contribution of smectite $(>30 \%)$ is observed during MIS3, whereas the lowest sea-level is observed during MIS2 (Fig. 2). Similarly, the calculated Unare River contribution is almost constant for MIS5ato- $d$ despite sea level fluctuations up to $25 \mathrm{~m}$ during this interval (Fig. 2). This indicates that provenance changes are not satisfactorily explained by sea-level fluctuations alone. 
272 lies in the belt of variation of the ITCZ, so that the average position of the northern 273 Hemisphere summer ITCZ and associated rainfalls influences the detrital flux. Presently, a seasonal modulation of the terrigenous contribution to the basin occurs, with the highest detrital discharge during the rainy season (Martinez et al., 2007). In addition, high rainfalls characterize the North of Venezuela, in particular the drainage basins of the Tuy and Neveri Rivers (Fig. 6A; Goldbrunner, 1984), which are affected by high runoff. Previous studies evidenced the influence of the ITCZ on precipitations patterns at orbital timescale (Peterson et al., 2000a; Haug et al., 2001; Chiang et al., 2003; Broccoli et al., 2006). During interglacials, the ITCZ has an average northward position and the associated precipitation belt lies over northern Venezuela (Fig. 6A). This is consistent with the observed enhanced contribution from the northern detrital sources during the Holocene and MIS5e (Fig. 5, Table 2). Conversely a southward move of the average position of the ITCZ during glacials favors rainfalls over the Venezuelan central plains while rainfalls over Northern Venezuela are reduced (Fig. 6C). As a consequence, a marked increase in the contribution from the Unare River (contributing up to $100 \%$ of the clay mineral association) is observed during the Last Glacial (Fig. 5, Table 2). This configuration could however also favor the southern part of the Neveri River drainage basin which is dominated by the same sedimentary rocks as the Unare River drainage basin. A contribution of the Neveri River with a similar clay association as the Unare River is therefore possible (Fig. 6C). The better correlation of clay mineral contents with planktonic $\delta^{18} \mathrm{O}$ variations (reflecting SST variations) than with the global benthic $\delta^{18} \mathrm{O}$ variations (reflecting ice-volume and sea-level; Table S4) also gives support to a dominant climatic influence, as the highest SST is associated to a northward position of the ITCZ

294 (Chiang et al., 2002; Chiang and Bitz, 2005).

\subsection{Interglacials}

Though according to Clayton et al. (1999) interglacials clay-mineral contents are generally similar, our dataset show marked differences between the Holocene and Eemian (Fig. 2, Table 1). The Eemian sediments are depleted in smectite (17\%), and enriched in kaolinite (35\%) and illite (27\%). By contrast, the low smectite content (22\%) in Holocene samples is counterbalanced by a higher contribution of IS (11\%). As two distinct sediment cores are used to record the two time intervalsdMD03-2625 for the Holocene and ODP 1002 for the Eemian-these differences might be related to the different core locations within the basin. Core MD03-2625 (NE flank of the central saddle, Fig. 1) should be more influenced by 
Margarita region. Consistently, a high contribution of mixed layer IS is observed in Holocene samples (Fig. 2, Table 1), a clay mineral which is very specific of the eastern detrital sources (Bout-Roumazeilles et al., 2013). The very high IS content in Holocene sediments points to a marked contribution from the Manzanares River, however, the low Esquevin index (Fig. 4) rather points to a contribution from the Araya region (Bout- Roumazeilles et al., 2013). This latter contribution is also suggested by the distribution of data in the $\mathrm{I} / \mathrm{S}$ vs $\mathrm{I} /(\mathrm{C}+\mathrm{K})$ plot (Fig. 5). From the low clay-mineral content of the sediments located in the northeastern platform,

313 Bout-Roumazeilles et al. (2013) concluded that these sources likely were of minor influence 314 for the sedimentation in the deep Cariaco Basin. Flooding events and seismic activity along the El Pilár fault have been proved responsible for depositional events in the eastern Cariaco sub-basin (Thunell et al., 1999; Lorenzoni et al., 2012). During these events, clay-rich sediment (Elmore, 2005) remobilized from the eastern side of the Cariaco Basin and/or from the Gulf of Cariaco is delivered to the deep basin by turbidity currents flowing along the Manzanares River Canyon (Lorenzoni et al., 2012). The abundant microturbidites in the sediments of the eastern sub-basin, including on the eastern flank of the central saddle (Hughen et al., 1996a), confirms the frequent occurrence of small turbiditic events and suggests that the contribution of this eastern source has been underestimated by BoutRoumazeilles et al. (2013). We can thus assume that the increased contribution of IS during the Holocene partly results from the eastward location of core MD03-2625 compared with the ODP 1002. Nevertheless, the $\mathrm{I} / \mathrm{S}$ and $\mathrm{I} /(\mathrm{C}+\mathrm{K})$ ratios both point out a significant contribution from the Neveri River (20\%) during the Eemian compared to the Holocene (ca 0\%, Table 1, Fig. 5 middle). Such modification of provenance could not result from respective locations of the two studied cores, because core ODP 1002 (W side of the central saddle, Fig. 1) is located farther from the Neveri River than core MD03-2625. Moreover, the higher I/S ratio of the Eemian (1.94) compared to the Holocene (1.04) indicates a severe decrease of the Unare River contribution during the Eemian. As a whole, these data suggest a higher contribution of northern Venezuela sources during the Eemian compared with the Holocene (Fig. 6D).

The Eemian interglacial was substantially different from the Holocene, with a generally warmer climate and higher sea level (Kukla et al., 2002; Rohling et al., 2008; OttoBliesner et al., 2013). This difference results from slightly different orbital parameters, which led to higher mean insolation during the Eemian than during the Holocene. Several characteristics of the sediments of the Cariaco Basin such as the total organic carbon content, detrital content, $\mathrm{d} 13 \mathrm{C}$ and $\mathrm{d} 15 \mathrm{~N}$ of the organic matter, present contrasting values between the 
Drenzek, 2007). Alkenone data in the Cariaco Basin indicate that Eemian SST was up to $2{ }^{\circ} \mathrm{C}$ warmer than during the Holocene (Hebert and Schuffert, 2000). Models indicate that the higher mean summer insolation at $10^{\circ} \mathrm{N}$ during the Eemian compared with the Holocene resulted in a more northerly position of the ITCZ, enhanced seasonality and more humid conditions over Northern South America (Nikolova et al., 2013). Our clay mineral data suggesting enhanced rainfall on the Coastal Range while the Unare River drainage basin experienced reduced precipitations, give strong support to a northward displacement of the mean ITCZ location during the Eemian (Fig. 6D).

The illite content rapidly decreases at the transition between MIS5e and MIS5d (Fig. 2). The calculated contribution from the northern detrital sources also decreases and the Unare contribution during MIS5d is comparable to Holocene value (Fig. 5, Table 2). This suggests a southward move of summer ITCZ at the end of MIS5e to a position close to the Holocene position (Fig. 6A), though alkenone data still document high SST in the basin during MIS5d (Hebert and Schuffert, 2000), similarly to other low latitude paleoclimatic records (Kukla et al., 2002). In that frame, the rapid decrease in illite synchronous with the North Atlantic C26 cold event (Chapman and Shackleton, 1999; Lehman et al., 2002) (Fig. 4), suggests a strong forcing of high latitude climatic variations on the modulation of ITCZ shifts (Chiang et al., 2003).

\section{3. $20-70 \mathrm{ka}$}

At orbital timescale, the basic glacial-interglacial variations of the terrigenous supply to the Cariaco Basin, linked to contrasted mean latitudinal position of the ITCZ and/or to sea level variations (x4.1) do not satisfactorily explain the peculiar clay composition observed during MIS3. Indeed, while kaolinite and smectite are the major components of the whole glacial period, MIS3 is enriched in smectite (K/S 1/4 1.09) compared with MIS2 and MIS4 (K/S 1/4 1.44 and 1.31 respectively; Table 1). The global distribution of MIS3 samples in the $\mathrm{I} /(\mathrm{C}+\mathrm{K})$ vs I/S diagram points out a smectite-rich source (Fig. 4), characterized by a K/S ratio not corresponding to any of present-day local end-members (K/S of the Unare River 1/4 1.5). This specific smectite supply may not result from changing provenance but is better explained by modifications of weathering conditions in the Unare River drainage basin during MIS3 compared to full glacial conditions. Indeed, smectite formation is favored in poorly drained soils (Wilson, 1999). Models indicate that precipitations were globally higher during MIS3 compared to LGM especially in the tropics and inter-tropical domains, associated with a higher seasonality during MIS3 compared to full glacial conditions (Van Meerbeeck et al., 
2009). Enhanced rainfall associated with contrasted seasonal precipitations concentrated on the poorly-drained great plains area, due to the mean southward position of the ITCZ during glacials, likely favored the formation of abundant smectite. The enhanced contribution of smectite versus kaolinite thus likely reflects the combined effect of insolation and seasonality on weathering, leading to a clay association which has no present-day analog.

At millennial scale, latitudinal fluctuations of the ITCZ have been proposed, with a northern position of the ITCZ during interstadials and a southern position during stadials (Peterson et al., 2000a; Peterson and Haug, 2006; Deplazes et al., 2013). Nevertheless, the evolution of the clay mineral assemblages through the $20 \mathrm{e} 70 \mathrm{ka}$ interval (Fig. 3) does not particularly reflect changes in the source of detrital inputs. The relatively similar clay mineral assemblages in laminated and bioturbated intervals indicate that from MIS4 to the LGM, the source of clay minerals broadly remained the same and was largely dominated by inputs from the Unare River. This implies that even if the latitudinal position of the ITCZ fluctuated in relation to stadial/interstadial cycles (Peterson et al., 2000a; Peterson and Haug, 2006; Deplazes et al., 2013), the summer ITCZ remained in a relatively southward latitudinal position and never reached the drainage basin of the Tuy and Neveri rivers (Fig. 6C). Millennial scale oscillations of the K/S ratio over this interval (Fig. 3) however suggest variations in runoff intensity or erosion type, which likely altered the kaolinite-to-smectite ratio (Stern et al., 1991). The K/S ratio is low during interstadials, whereas it is maximum during stadials (Fig. 3). The higher smectite content observed in the laminated stadial sediments is coeval with an increased terrigenous fraction (Peterson et al., 2000a; Peterson and Haug, 2006; González et al., 2008a) (Figs. 3 and S4). It is consistent with increased runoff due to a northerly position of summer ITCZ and/or increased seasonality during these periods (Fig. 6C). Conversely, the higher kaolinite content during, or at the beginning of, Heinrich-like events (Fig. 3) associated to smaller grains could reflect decreased runoff and therefore more arid conditions during these periods (Peterson et al., 2000a; Peterson and Haug, 2006; González et al., 2008a) and/or could result from slight decrease of seasonality, which favor kaolinite versus smectite formation (Fig. 6C).

Palynological data from the Cariaco sediments suggest rapid sea-level rises during the course of Heinrich-like events (González and Dupont, 2009), promoting remobilization of sediments from the Unare platform. Clay mineral analyses of surface sediments from the Unare platform indicate that these sediments are rich in kaolinite compared to the sediment deposited at the river mouths, due to differential sedimentation (Bout-Roumazeilles et al., 2013). The high kaolinite content at the beginning of Heinrich-like events (Fig. 3) is also 
associated to a decrease of the mean grain size of the sediment (Fig. 4). This suggests that

409 Heinrich-like events are associated to the delivery of clayey kaolinite-rich sediments eroded 410 from the Unare platform, consistent with the global rapid sea-level rise at the beginning of 411 Heinrich-like events (Siddall et al., 2003; Rohling et al., 2004; González and Dupont, 2009). 412 Supporting this interpretation, several rapid sea level fluctuations are locally documented in 413 the Gulf of Cariaco during MIS3, that were associated to Heinrich events 4e6 (Van Daele et 414 al., 2011).

During MIS6, MIS5 and MIS2, some peaks in kaolinite content evidenced by changes of either $\mathrm{K} / \mathrm{I}$ or $\mathrm{K} / \mathrm{S}$ ratios are associated to modifications of the sedimentary characteristics (Fig. 4): a decrease of the mean grain size (Fig. 4) and/or changes in the magnetic 418 susceptibility (Fig. S3). All these kaolinite peaks are coeval to North Atlantic cold events 419 (Chapman and Shackleton, 1999; Lehman et al., 2002). Even if comparison with detailed sea420 level variation curves (Siddall et al., 2003; Rohling et al., 2004, 2008) indicates that most 421 peaks also correspond to periods of rapid sea level rises, their distribution in the I/S vs I/(C + $422 \mathrm{~K}$ ) plot is relatively different from that of Unare platform samples (Fig. S5), suggesting that these kaolinite-rich intervals do not result from sediment remobilization, but rather reflect high-latitude forcings on low-latitude climatic conditions.

\subsection{Younger Dryas e Termination II}

The Younger Dryas (YD) sediments of the Cariaco Basin are characterized by a relatively high illite content and a marked drop in kaolinite content, resulting in especially high values of the $\mathrm{I} / \mathrm{K}$ ratio (up to $>3$; Fig. 4). Moreover, the $\mathrm{YD}$ is characterized by a specific supply in IS (19\%) in both MD02-2625 and ODP 1002 cores. As discussed for the Holocene, the high IS content suggests enhanced contribution from the Araya/Manzanares area. In the $\mathrm{I} / \mathrm{S}$ vs $\mathrm{I} /(\mathrm{C}+\mathrm{K})$ diagram, YD samples plot out of the Unare-Neveri-Tuy triangle (Fig. 5), pointing to an additional contribution by the Araya area. However the peculiar $\mathrm{I} / \mathrm{K}$ ratio observed during the YD raises the question of a possible eolian contribution in the Cariaco Basin. In low latitudes where the Cariaco Basin is located, intervals of high eolian activity mostly correspond to the Younger Dryas and Heinrich-like events (deMenocal et al., 2000a; Jullien et al., 2007; Itambi et al., 2009). In particular, strong wind activity over North Africa (Lancaster et al., 2002) and high inputs of eolian material in western tropical Atlantic during the YD are well documented (deMenocal et al., 2000a; Jullien et al., 2007). Evidence for strong wind activity in Venezuela during the YD is also given by the dune fields of the Orinoco plains, where the most recent dune generation rests on a paleosol dated to $11.114 \mathrm{C}$ 
ka (Clapperton, 1993).

Saharan air-borne particles recovered at Barbados are dominated by illite or kaolinite (Glaccum and Prospero, 1980; Caquineau et al., 1998, 2002). Recent data from the coast of

445 Senegal -acquired in our laboratory with the same analytical protocol (Skonieczny et al., 446 2013)- allow direct comparison with the Cariaco data. The comparison of both sides of the 447 Atlantic Ocean is moreover possible since the $\mathrm{I} / \mathrm{K}$ ratio of Saharan dust remains relatively 448 constant during the travel across the Atlantic Ocean (Glaccum and Prospero, 1980; Caquineau 449 et al., 1998). The $\mathrm{I} / \mathrm{K}$ ratio of the eolian material recovered in Senegal ranges between 0.57 450 and 0.81 , with a mean value of 0.62 (Skonieczny et al., 2013). These values are close to the 451 average value observed in the Cariaco sediments (Fig. 4), but much lower than the values 452 observed during the YD. The $\mathrm{I} / \mathrm{K}$ ratio of Saharan dust varies according to the source of the 453 material, and values up to 2.2 are observed in the North Western Sahara (Caquineau et al., 454 2002; Skonieczny et al., 2013). We cannot therefore rule out that the eolian material present 455 in the Cariaco Basin sediments during the YD originated from high $\mathrm{I} / \mathrm{K}$ areas of Northwestern 456 Africa. However, the source of the eolian contribution needs not being located in North 457 Africa: in the I/S vs I/(C + K) diagram, YD samples point towards the Araya-Margarita sector 458 (Fig. 5). The Araya-Margarita sector also shows high $\mathrm{I} / \mathrm{K}$ ratios $\left(1.4^{\mathrm{e}} 2.2\right)$, that are in the range 459 of the high values observed during the YD. The Araya-Margarita area is located upwind to the 460 Cariaco Basin and currently has a mostly semi-arid climate (Fig. 6A). It appears possible that 461 the generally windier conditions of the YD favored even drier conditions in the Araya462 Margarita area, soil erosion providing material for wind transport. Overall, these data are 463 consistent with a relatively southward position of the ITCZ during the YD, but characterized 464 by a very peculiar wind strength or wind pattern that had no equivalent during the climatic 465 cycle (Fig. 6B). The Preboreal interval (PB) has a clay mineral content that is intermediate 466 between those of the YD and Holocene (Table 1, Fig. 5), suggesting that the eolian 467 contribution did not stop immediately at the end of the YD, bur rather progressively faded 468 during the course of the PB.

469 Though lower than for the YD, high I/K ratios are also observed for MIS6-5 transition 470 (Fig. 4), associated with slightly enhanced IS contribution. When plotted on the I/S vs I/(C + $471 \mathrm{~K})$ diagram, samples from Termination II are shifted in the same direction as samples of the 472 YD, possibly also indicating an eolian contribution during that period. The sediment 473 deposited during the MIS6-5 transition somehow resembles the one deposited during the YD: 474 light colored laminations are clearly visible and diatoms are abundant (Peterson et al., 2002). 475 The presence of eolian material in the sediment of the MIS6-5 transition gives support to the 
hypothesis that YD-like windy conditions, promoting upwelling activity in the Cariaco Basin, existed during this interval. A cold YD-like event at the MIS6-5 transition has been described in several terrestrial and marine records (Seidenkrantz et al., 1996; Sánchez Goñi et al., 1999; Cannariato and Kennett, 2005). This "Termination II climate oscillation" as it is sometimes referred to, was of lower intensity than the YD (Kukla et al., 2002). Consistent with this observation, the Cariaco record showing a lower value of the $\mathrm{I} / \mathrm{K}$ ratio compared to the YD points to a lower eolian contribution and suggests reduced wind intensity.

\section{Conclusion}

Based on the recent reevaluation of the sources of clay minerals in the Cariaco Basin (Bout-Roumazeilles et al., 2013), our new record of clay mineral variations in the Cariaco sediments during the last climatic cycle allows to re-consider how climatic fluctuations were recorded by the detrital flux in this basin.

Smectite-rich sediments from the Unare River, representing a southern detrital source, dominate the clay-mineral flux to the central Cariaco Basin throughout the studied interval. Its contribution is almost exclusive during glacial, while an increased contribution of illiterich sediments from northern detrital sources is observed during interglacials. At orbital timescale, this change of the respective contributions of detrital sources mostly has a direct climatic origin and is linked to the mean latitudinal position of the ITCZ. Moreover, the clay composition of MIS3 suggests that the effect of insolation in driving the mean latitudinal position of the ITCZ (location of the precipitation belt, and total rainfall) is modulated by seasonality (monthly rain distribution), which modified the weathering regime of the drainage basin.

Rapid fluctuations of the clay mineral content during the Last Glacial are related to millennial Dansgaard-Oeschger oscillations and Heinrich-like events. These oscillations are likely linked with fluctuations of runoff intensity (Peterson et al., 2000a; Peterson and Haug, 2006), but the clay-mineral association rules out any significant change of the origin of the detrital flux. The observed variations of the clay-mineral content rather respond to slight increases of seasonality during interstadials while decreased seasonality and remobilization of sediment from the Unare platform associated to rapid sea level variations characterized Heinrich-like events and stadials.

The clay data clearly point for a significant eolian contribution to the Cariaco Basin during the Younger Dryas, confirming that this period was marked by high wind intensity in the subtropical belt. According to its clay-mineral content, this eolian material may originate 
510 from the Sahara and/or from the arid Araya-Margarita area. A similar eolian contribution is 511 also observed at the MIS6-5 transition pointing to the occurrence of a windy Younger Dryas512 like episode during Termination II.

\section{Acknowledgments}

We thank the Ocean Drilling Program and ODP curators for providing sediment samples from core 1002, as well as the IMAGES program and crew of the R/V Marion Dufresne. Nicholas Drenzek is acknowledged for sharing his $\delta^{18} \mathrm{O}$ data on G. ruber from core ODP 1002D. Lea-Marie Emaille, Deny Malengros and Kevin Hornez are acknowledged for their help in running grain size and clay mineral analyses. Financial support for this study was provided by the project « Enfouissement organique dans le bassin de Cariaco: contrôles climatique et diagénétique » through the French national EVE-CYBER-LEFE program (INSU-CNRS). Rick Murray and an anonymous reviewer are acknowledged for constructive comments on the manuscript.

References

Arbuszewski, J.A., deMenocal, P.B., Cleroux, C., Bradtmiller, L., Mix, A., 2013. Meridional shifts of the Atlantic intertropical convergence zone since the Last Glacial Maximum. Nat. Geosci. 6, 959-962.

529 Black, D.E., Peterson, L.C., Overpeck, J.T., Kaplan, A., Evans, M.N., Kashgarian, M., 1999. 530 Eight centuries of North Atlantic ocean atmosphere variability. Science 286 (5445), 17095311713.

532 Bout-Roumazeilles, V., Cortijo, E., Labeyrie, L., Debrabant, P., 1999. Clay mineral evidence 533 of nepheloid layer contributions to the Heinrich layers in the northwest Atlantic. Palaeogeogr. 534 Palaeoclimatol. Palaeoecol. 146 (1-4), 211-228.

535 Bout-Roumazeilles, V., Riboulleau, A., du Châtelet, E.A., Lorenzoni, L., Tribovillard, N., 536 Murray, R.W., Müller-Karger, F., Astor, Y.M., 2013. Clay mineralogy of surface sediments 537 as a tool for deciphering river contributions to the Cariaco Basin (Venezuela). J. Geophys. 538 Res. Oceans 118 (2), 750-761.

539 Braconnot, P., Otto-Bliesner, B., Harrison, S., Joussaume, S., Peterchmitt, J.-Y., Abe- Ouchi, 540 A., Crucifix, M., Driesschaert, E., Fichefet, T., Hewitt, C.D., et al., 2007. Results of PMIP2 541 coupled simulations of the mid-Holocene and Last Glacial Maximum e part 2: feedbacks with 542 emphasis on the location of the ITCZ and mid-and high latitudes heat budget. Clim. Past 3 543 (2), 279-296. 
544 Broccoli, A.J., Dahl, K.A., Stouffer, R.J., 2006. Response of the ITCZ to Northern 545 Hemisphere cooling. Geophys. Res. Lett. 33 (1), L01702.

546 Broecker, W.S., Putnam, A.E., 2013. Hydrologic impacts of past shifts of Earth's thermal 547 equator offer insight into those to be produced by fossil fuel CO2. Proc. Natl. Acad. Sci. 548 http://dx.doi.org/10.1073/pnas.1301855110.

549 Brown, G., Brindley, G.W., 1980. X-ray diffraction procedures for clay mineral 550 identification. In: Brindley, G.W., Brown, G. (Eds.), Crystal Structures of Clay Minerals and 551 Their X-ray Identification. Mineralogical Society, London, pp. 305-359.

552 Cannariato, K.G., Kennett, J.P., 2005. Structure of the penultimate deglaciation along the 553 California margin and implications for Milankovitch theory. Geology 33 (2), 157-160.

554 Caquineau, S., Gaudichet, A., Gomes, L., Legrand, M., 2002. Mineralogy of Saharan dust 555 transported over northwestern tropical Atlantic Ocean in relation to source regions. J. 556 Geophys. Res. 107 (D15), 4251.

557 Caquineau, S., Gaudichet, A., Gomes, L., Magonthier, M., Claude, Chatenet, B., 1998. 558 Saharan dust: clay ratio as a relevant tracer to assess the origin of soil-derived aerosols. 559 Geophys. Res. Lett. 25 (7), 983-986.

560 Chamley, H., 1989. Clay Sedimentology. Springer Verlag, Berlin.

561 Chapman, M.R., Shackleton, N.J., 1999. Global ice-volume fluctuations, North Atlantic ice562 rafting events, and deep-ocean circulation changes between 130 and 70 ka. Geology 27 (9), $563 \quad 795-798$.

564 Chiang, J.C.H., 2009. The tropics in paleoclimate. Annu. Rev. Earth Planet. Sci. 37 (1), 263565297.

566 Chiang, J.C.H., Biasutti, M., Battisti, D.S., 2003. Sensitivity of the Atlantic intertropical 567 convergence zone to Last Glacial Maximum boundary conditions. Paleoceanography 18 (4), 5681094.

569 Chiang, J.C.H., Kushnir, Y., Giannini, A., 2002. Deconstructing Atlantic Intertropical 570 Convergence Zone variability: influence of the local cross-equatorial sea surface temperature 571 gradient and remote forcing from the eastern equatorial Pacific. J. Geophys. Res. Atmos. 107 572 (D1). ACL 3-1.

573 Chiang, J.H., Bitz, C., 2005. Influence of high latitude ice cover on the marine Intertropical 574 Convergence Zone. Clim. Dyn. 25 (5), 477-496.

575 Clapperton, C.M., 1993. Quaternary Geology and Geomorphology of South America. 576 Elsevier, Amsterdam.

577 Clayton, T., Pearce, R.B., Peterson, L.C., 1999. Indirect climatic control of the clay mineral 
composition of Quaternary sediments from the Cariaco Basin, northern Venezuela (ODP Site 1002). Mar. Geol. 161 (2-4), 191-206.

Van Daele, M., van Welden, A., Moernaut, J., Beck, C., Audemard, F., Sanchez, J., Jouanne, F., Carrillo, E., Malavé, G., Lemus, A., et al., 2011. Reconstruction of Late- Quaternary seaand lake-level changes in a tectonically active marginal basin using seismic stratigraphy: the Gulf of Cariaco, NE Venezuela. Mar. Geol. 279 (1-4), 37-51.

deMenocal, P., Ortiz, J., Guilderson, T., Adkins, J., Sarnthein, M., Baker, L., Yarusinsky, M., 2000a. Abrupt onset and termination of the African Humid Period: rapid climate responses to gradual insolation forcing. Quat. Sci. Rev. 19 (1-5), 347-361.

deMenocal, P., Ortiz, J., Guilderson, T., Sarnthein, M., 2000b. Coherent high- and lowlatitude climate variability during the Holocene Warm Period. Science 288, 2198-2202.

Deplazes, G., Luckge, A., Peterson, L.C., Timmermann, A., Hamann, Y., Hughen, K.A., Rohl, U., Laj, C., Cane, M.A., Sigman, D.M., et al., 2013. Links between tropical rainfall and North Atlantic climate during the Last Glacial period. Nat. Geosci. 6 (3), 213-217.

Drenzek, N.J., 2007. The Temporal Dynamics of Terrestrial Organic Matter Transfer to the Oceans: Initial Assessment and Application ( $\mathrm{PhD}$ thesis). Massachussets Institute of Technology, 227p.

Elmore, A.C., 2005. Sedimentological Signatures of Transient Depositional Events in Cariaco Basin, Venezuela (Master thesis). University of South Carolina, 72p.

Esquevin, J., 1969. Influence de la composition chimique des argiles sur la cristallinité. Bull. du Cent. Rech. Pau-S.N.P.A. 3, 147-154.

Fagel, N., Robert, C., Hillaire-Marcel, C., 1996. Clay mineral signature of the NW Atlantic boundary undercurrent. Mar. Geol. 130 (1-2), 19-28.

Fagel, N., Robert, C., Preda,M., Thorez, J., 2001. Smectite composition as a tracer of deep circulation: the case of theNorthernNorthAtlantic.Mar. Geol.172 (3-4), 309-330.

Fleitmann, D., Burns, S.J., Mangini, A., Mudelsee, M., Kramers, J., Villa, I., Neff, U., AlSubbary, A.A., Buettner, A., Hippler, D., et al., 2007. Holocene ITCZ and Indian monsoon dynamics recorded in stalagmites from Oman and Yemen (Socotra). Quat. Sci. Rev. 26 (1-2), 170-188.

Glaccum, R.A., Prospero, J.M., 1980. Saharan aerosols over the tropical North Atlantic e mineralogy. Mar. Geol. 37 (3-4), 295-321.

Goldbrunner, A.W., 1984. Atlas climológico de Venezuela 1951-1970. Servicio de Meteorología de la Fuerza Aérea Venezolana, Maracay, Venezuela.

611 Goni, M.A., Thunell, R.C., Woodwort, M.P., Müller-Karger, F.E., 2006. Changes in wind- 
612 driven upwelling during the last three centuries: interocean teleconnections. Geophys. Res. 613 Lett. 33 (15), L15604.

614 González, C., Dupont, L.M., 2009. Tropical salt marsh succession as sea-level indicator 615 during Heinrich events. Quat. Sci. Rev. 28 (9-10), 939-946.

616 González, C., Dupont, L.M., Behling, H., Wefer, G., 2008a. Neotropical vegetation response 617 to rapid climate changes during the Last Glacial period: palynological evidence from the 618 Cariaco Basin. Quat. Res. 69 (2), 217-230.

619 González, C., Dupont, L.M., Mertens, K., Wefer, G., 2008b. Reconstructing marine 620 productivity of the Cariaco Basin during marine isotope stages 3 and 4 using organic-walled dinoflagellate cysts. Paleoceanography 23, PA3215. Hackley, P.C., Urbani, F., Karlsen, A.W., Garrity, C.P., 2006. Mapa Geológico de Venezuela 623 a Escala 1:750,000.

624 Haug, G.H., Hughen, K.A., Sigman, D.M., Peterson, L.C., Rohl, U., 2001. Southward 625 migration of the intertropical convergence zone through the Holocene. Science 293 (5533), $626 \quad 1304-1308$.

627 Haug, G.H., Pedersen, T.F., Sigman, D.M., Calvert, S.E., Nielsen, B., Peterson, L.C., 1998. 628 Glacial/Interglacial variations in production and nitrogen fixation in the Cariaco Basin during 629 the last 580 kyr. Paleoceanography 13 (5), 427-432.

630 Hebert, T.D., Schuffert, J.D., 2000. Alkenone unsaturation estimates of sea surface 631 temperatures at site 1002 over a full glacial cycle. In: Leckie, R.M., Sigurdsson, H., Acton, 632 G.D., Draper, G. (Eds.), Proceedings of the ODP, Scientific Results, pp. 237-247.

633 Hessler, I., Dupont, L., Bonnefille, R., Behling, H., González, C., Helmens, K.F., 634 Hooghiemstra, H., Lebamba, J., Ledru, M.-P., Lézine, A.-M., et al., 2010. Millennial- scale changes in vegetation records from tropical Africa and South America during the Last 636 Glacial. Quat. Sci. Rev. 29 (21-22), 2882-2899.

637 Hoerling, M.P., Hurrell, J.W., Xu, T., 2001. Tropical origins for recent North Atlantic climate 638 change. Science 292 (5514), 90-92.

639 Hughen, K., Lehman, S., Southon, J., Overpeck, J., Marchal, O., Herring, C., Turnbull, J., 640 2004. 14C activity and global carbon cycle changes over the past 50,000 years. Science 303 641 (5655), 202-207.

642 Hughen, K., Southon, J., Lehman, S., Bertrand, C., Turnbull, J., 2006. Marine-derived 14C 643 calibration and activity record for the past 50,000 years updated from the Cariaco Basin. 644 Quat. Sci. Rev. 25 (23-24), 3216-3227.

645 Hughen, K.A., Overpeck, J.T., Peterson, L.C., Anderson, R.F., 1996a. The nature of varved 
646 sedimentation in the Cariaco Basin, Venezuela, and its paleoclimatic significance. In: Kemp, 647 A.E.S. (Ed.), Palaeoclimatology and Palaeoceanography from Laminated Sediments. 648 Geological Society, London, pp. 171-183.

649 Hughen, K.A., Overpeck, J.T., Peterson, L.C., Trumbore, S., 1996b. Rapid climate changes in 650 the tropical Atlantic region during the last deglaciation. Nature 380 (6569), 51-54.

651 Hughen, K.A., Southon, J.R., Lehman, S.J., Overpeck, J.T., 2000. Synchronous radiocarbon 652 and climate shifts during the last deglaciation. Science 290 (5498), 1951-1954.

653 Itambi, A.C., von Dobeneck, T., Mulitza, S., Bickert, T., Heslop, D., 2009. Millennialscale 654 northwest African droughts related to Heinrich events and Dansgaard- Oeschger cycles: 655 evidence in marine sediments from offshore Senegal. Paleoceanography 24 (1), PA1205.

656 Ivanochko, T.S., Ganeshram, R.S., Brummer, G.-J.A., Ganssen, G., Jung, S.J.A., Moreton, 657 S.G., Kroon, D., 2005. Variations in tropical convection as an amplifier of global climate 658 change at the millennial scale. Earth Planet. Sci. Lett. 235 (1²), 302-314.

659 Jullien, E., Grousset, F., Malaizé, B., Duprat, J., Sanchez-Goni, M.F., Eynaud, F., Charlier, 660 K., Schneider, R., Bory, A., Bout, V., et al., 2007. Low-latitude “dusty events" vs. high661 latitude “icy Heinrich events.” Quat. Res. 68 (3), 379-386.

662 Kukla, G.J., Bender, M.L., de Beaulieu, J.-L., Bond, G., Broecker, W.S., Cleveringa, P., 663 Gavin, J.E., Herbert, T.D., Imbrie, J., Jouzel, J., et al., 2002. Last Interglacial climates. Quat. 664 Res. 58 (1), 2-13.

665 Lachniet, M.S., Asmerom, Y., Burns, S.J., Patterson, W.P., Polyak, V.J., Seltzer, G.O., 2004. 666 Tropical response to the $8200 \mathrm{yr}$ B.P. cold event? Speleothem isotopes indicate a weakened 667 early Holocene monsoon in Costa Rica. Geology 32 (11), 957-960.

668 Lachniet, M.S., Johnson, L., Asmerom, Y., Burns, S.J., Polyak, V., Patterson, W.P., Burt, L., 669 Azouz, A., 2009. Late Quaternary moisture export across Central America and to Greenland: 670 evidence for tropical rainfall variability from Costa Rican stalagmites. Quat. Sci. Rev. 28 (27$67128), 3348-3360$.

672 Laj, C., Shipboard Scientific Party, 2004. MD132/IMAGES XI, PICASSO Cruise Report. 673 Lancaster, N., Kocurek, G., Singhvi, A., Pandey, V., Deynoux, M., Ghienne, J.-F., Lo, K., 674 2002. Late Pleistocene and Holocene dune activity and wind regimes in the western Sahara 675 Desert of Mauritania. Geology 30 (11), 991-994.

676 Lea, D.W., Pak, D.K., Peterson, L.C., Hughen, K.A., 2003. Synchroneity of tropical and high677 latitude Atlantic temperatures over the Last Glacial termination. Science 301 (5638), 13616781364.

679 Lea, D.W., Pak, D.K., Spero, H.J., 2000. Climate impact of Late Quaternary equatorial 
680 Pacific sea surface temperature variations. Science 289 (5485), 1719-1724.

681 Leduc, G., Vidal, L., Tachikawa, K., Rostek, F., Sonzogni, C., Beaufort, L., Bard, E., 2007.

682 Moisture transport across Central America as a positive feedback on abrupt climatic changes.

683 Nature 445 (7130), 908-911.

684 Lehman, S.J., Sachs, J.P., Crotwell, A.M., Keigwin, L.D., Boyle, E.A., 2002. Relation of 685 subtropical Atlantic temperature, high-latitude ice rafting, deep water formation, and 686 European climate 130,000e60,000 years ago. Quat. Sci. Rev. 21 (18¹9), 1917-1924.

687 Lisiecki, L.E., Raymo, M.E., 2005. A Pliocene-Pleistocene stack of 57 globally distributed 688 benthic $\delta^{18} \mathrm{O}$ records. Paleoceanography 20 (1), PA1003.

689 Lorenzoni, L., Benitez-Nelson, C.R., Thunell, R.C., Hollander, D., Varela, R., Astor, Y., 690 Audemard, F.A., Muller-Karger, F.E., 2012. Potential role of event-driven sediment transport 691 on sediment accumulation in the Cariaco Basin, Venezuela. Mar.

692 Geol. 307-310 (0), 105-110.

693 Martinez, N.C., Murray, R.W., Thunell, R.C., Peterson, L.C., Muller-Karger, F., Astor, Y., 694 Varela, R., 2007. Modern climate forcing of terrigenous deposition in the tropics (Cariaco 695 Basin, Venezuela). Earth Planet. Sci. Lett. 264 (3-4), 438-451.

696 Martinez, N.C., Murray, R.W., Thunell, R.C., Peterson, L.C., Muller-Karger, F., Lorenzoni, 697 L., Astor, Y., Varela, R., 2010. Local and regional geochemical signatures of surface 698 sediments from the Cariaco Basin and Orinoco Delta, Venezuela. Geology 38 (2), 159-162.

699 Van Meerbeeck, C.J., Renssen, H., Roche, D.M., 2009. How did Marine Isotope Stage 3 and 700 Last Glacial Maximum climates differ? - Perspectives from equilibrium simulations. Clim. 701 Past 5 (1), 33-51.

702 Montero-Serrano, J.-C., Bout-Roumazeilles, V., Carlson, A.E., Tribovillard, N., Bory, A., 703 Meunier, G., Sionneau, T., Flower, B.P., Martinez, P., Billy, I., et al., 2011. Contrasting 704 rainfall patterns over North America during the Holocene and Last Interglacial as recorded by 705 sediments of the northern Gulf of Mexico. Geophys. Res. Lett. 38 (14), L14709.

706 Montero-Serrano, J.C., Bout-Roumazeilles, V., Tribovillard, N., Sionneau, T., Riboulleau, A., 707 Bory, A., Flower, B., 2009. Sedimentary evidence of deglacial megafloods in the northern 708 Gulf of Mexico (Pigmy Basin). Quat. Sci. Rev. 28 (27e28), 3333-3347.

709 Muller-Karger, F., Varela, R., Thunell, R., Scranton, M., Bohrer, R., Taylor, G., Capelo, J., 710 Astor, Y., Tappa, E., Ho, T.Y., et al., 2001. Annual cycle of primary production in the 711 Cariaco Basin: response to upwelling and implications for vertical export. J. Geophys. Res.712 Oceans $106(\mathrm{C} 3), 4527-4542$.

713 Nikolova, I., Yin, Q., Berger, A., Singh, U.K., Karami, M.P., 2013. The Last Interglacial 
714 (Eemian) climate simulated by LOVECLIM and CCSM3. Clim. Past 9 (4), 1789¹806.

715 Otto-Bliesner, B.L., Rosenbloom, N., Stone, E.J., McKay, N.P., Lunt, D.J., Brady, E.C., 716 Overpeck, J.T., 2013. How warm was the Last Interglacial? New modeledata comparisons. 717 Philos. Trans. R. Soc. Math. Phys. Eng. Sci. 371, 20130097.

718 Paillard, D., Labeyrie, L., Yiou, P., 1996. Macintosh program performs time-series analysis. 719 Eos 77, 379.

720 Peterson, L.C., Haug, G.H., 2006. Variability in the mean latitude of the Atlantic Intertropical 721 Convergence Zone as recorded by riverine input of sediments to the Cariaco Basin 722 (Venezuela). Palaeogeogr. Palaeoclimatol. Palaeoecol. 234 (1), 97e113.

723 Peterson, L.C., Haug, G.H., Hughen, K.A., Rohl, U., 2000a. Rapid changes in the hydrologic cycle of the tropical Atlantic during the Last Glacial. Science 290 (5498), 1947-1951.

Peterson, L.C., Haug, G.H., Murray, R.W., Yarincik, K.M., King, J.W., Bralower, T.J., Kameo, K., Rutherford, S.D., Pearce, R.B., 2000b. Late Quaternary stratigraphy and sedimentation at ODP site 1002, Cariaco Basin (Venezuela). In: Leckie, R.M., Sigurdsson, H., Acton, G.D., Draper, G. (Eds.), Proceedings of the ODP, Scientific Results, pp. 85-99. Peterson, L.C., O’Hara, C., Haug, G.H., Lin, H., 2002. Deglacial events in the cariaco Basin during terminations I and II. AGU Fall Meet. Abstr., B8.

731 Peterson, L.C., Overpeck, J.T., Kipp, N.G., Imbrie, J., 1991. A high-resolution Late 732 Quaternary upwelling record from the anoxic Cariaco Basin, Venezuela. Paleoceanography 6, 733 99-119.

734 Petschick, R., 2002. MacDiff 4.2 Manual. MacDiff [Online]. Available from World Wide 735 Web: http://www.geol-pal.uni-frankfurt.de/Staff/Homepages/Petschick/ Petschick.html.

736 Petschick, R., Kuhn, G., Gingele, F., 1996. Clay mineral distribution in surface sediments of 737 the South Atlantic: sources, transport, and relation to oceanography. Mar. Geol. 130 (3e4), $738 \quad 203-229$.

739 Placzek, C.J., Quade, J., Patchett, P.J., 2013. A $130 \mathrm{ka}$ reconstruction of rainfall on the 740 Bolivian Altiplano. Earth Planet. Sci. Lett. 363 (0), 97-108.

741 Rohling, E.J., Grant, K., Hemleben, C., Siddall, M., Hoogakker, B.A.A., Bolshaw, M., 742 Kucera, M., 2008. High rates of sea-level rise during the Last Interglacial period. Nat. Geosci. $7431(1), 38-42$.

744 Rohling, E.J., Marsh, R., Wells, N.C., Siddall, M., Edwards, N.R., 2004. Similar meltwater 745 contributions to glacial sea level changes from Antarctic and northern ice sheets. Nature 430 746 (7003), 1016-1021.

747 Romanova, V., Prange, M., Lohmann, G., 2004. Stability of the glacial thermohaline 
748 circulation and its dependence on the background hydrological cycle. Clim. Dyn. 22 (5), $527-$ 749538.

750 Ruddiman, W.F., 2001. Earth's Climate: Past and Future. W.H. Freeman, 465 p. Sánchez 751 Goñi, M.F., Eynaud, F., Turon, J.L., Shackleton, N.J., 1999. High resolution palynological 752 record off the Iberian margin: direct land-sea correlation for the Last Interglacial complex. 753 Earth Planet. Sci. Lett. 171 (1), 123-137.

754 Schumm, S.A., 1993. River response to baselevel change: implications for sequence 755 stratigraphy. J. Geol. 101 (2), 279-294.

756 Seidenkrantz, M.-S., Bornmalm, L., Johnsen, S.J., Knudsen, K.L., Kuijpers, A., Lauritzen, S.757 E., Leroy, S.A.G., Mergeal, I., Schweger, C., Van Vliet-Lanoë, B., 1996. Two-step 758 deglaciation at the Oxygen Isotope Stage 6/5E transition: the Zeifen- Kattegat climate 759 oscillation. Quat. Sci. Rev. 15 (1), 63-75.

760 Shipboard Scientific Party, 1997. Site 1002. In: Sigurdsson, H., Leckie, R.M., Acton, G.D., et 761 al. (Eds.), Proceedings of the Ocean Drilling Program, Initial Reports, pp. 359-373.

762 Siddall, M., Rohling, E.J., Almogi-Labin, A., Hemleben, C., Meischner, D., Schmelzer, I., 763 Smeed, D.A., 2003. Sea-level fluctuations during the Last Glacial cycle. Nature 423 (6942), $764 \quad 853-858$.

765 Skonieczny, C., Bory, A., Bout-Roumazeilles, V., Abouchami, W., Galer, S.J.G., Crosta, X., 766 Diallo, A., Ndiaye, T., 2013. A three-year time series of mineral dust deposits on the West 767 African margin: sedimentological and geochemical signatures and implications for 768 interpretation of marine paleo-dust records. Earth Planet. Sci. Lett. 364, 145-156.

769 Sperazza, M., Moore, J.N., Hendrix, M.S., 2004. High-resolution particle size analysis of 770 naturally occurring very Fine-Grained sediment through laser diffractometry. J. Sediment. 771 Res. 74 (5), 736-743.

772 Stern, R., Ben-Hur, M., Shainberg, I., 1991. Clay mineralogy effect on rain infiltration, seal 773 formation and soil losses. Soil Sci. 152 (6), 455-462.

774 Thunell, R., Tappa, E., Varela, R., Llano, M., Astor, Y., Muller-Karger, F., Bohrer, R., 1999. 775 Increased marine sediment suspension and fluxes following an earthquake. Nature 398 776 (6724), 233-236.

777 Wang, X., Auler, A.S., Edwards, R.L., Cheng, H., Cristalli, P.S., Smart, P.L., Richards, D.A., 778 Shen, C.-C., 2004. Wet periods in northeastern Brazil over the past 210 kyr linked to distant 779 climate anomalies. Nature 432 (7018), 740-743.

780 Wang, Y.J., Cheng, H., Edwards, R.L., An, Z.S., Wu, J.Y., Shen, C.C., Dorale, J.A., 2001. A 781 high-resolution absolute-dated late Pleistocene monsoon record from Hulu Cave, China. 
782 Science 294 (5550), 2345-2348. Wilson, M.J., 1999. The origin and formation of clay 783 minerals in soils; past, present

784 and future perspectives. Clay Miner. 34 (1), 7e25. Yarincik, K.M., Murray, R.W., Peterson, 785 L.C., 2000. Climatically sensitive eolian and

786 hemipelagic deposition in the Cariaco Basin, Venezuela, over the past 578,000 years: results 787 from Al/Ti and K/Al. Paleoceanography 15 (2), 210-228.

788

\section{Figures Caption}

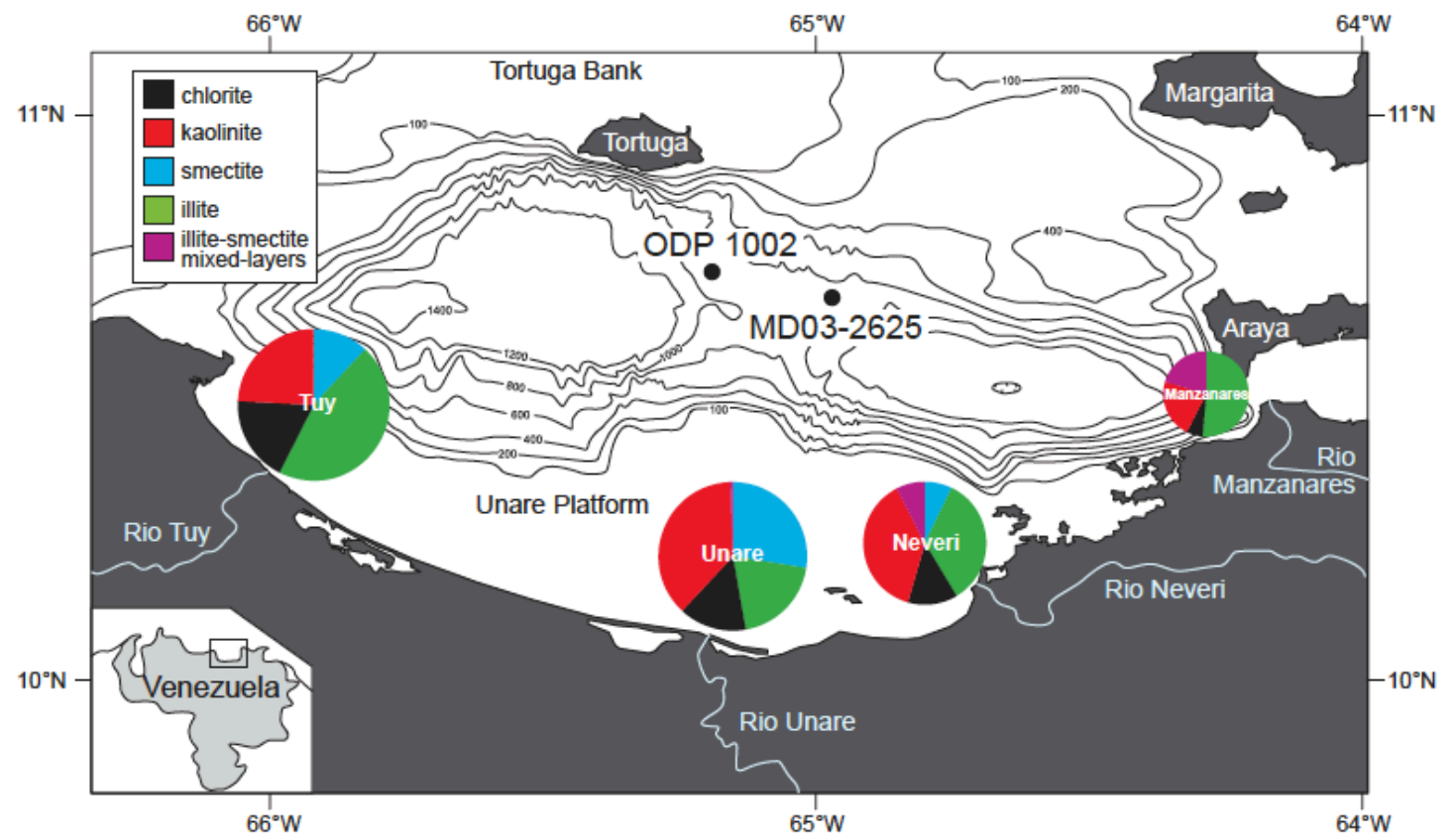

791 Fig. 1. Bathymetry of the Cariaco Basin and location of the cores used in this study. Average clay 792 distribution at river mouths from Bout-Roumazeilles et al. (2013). 


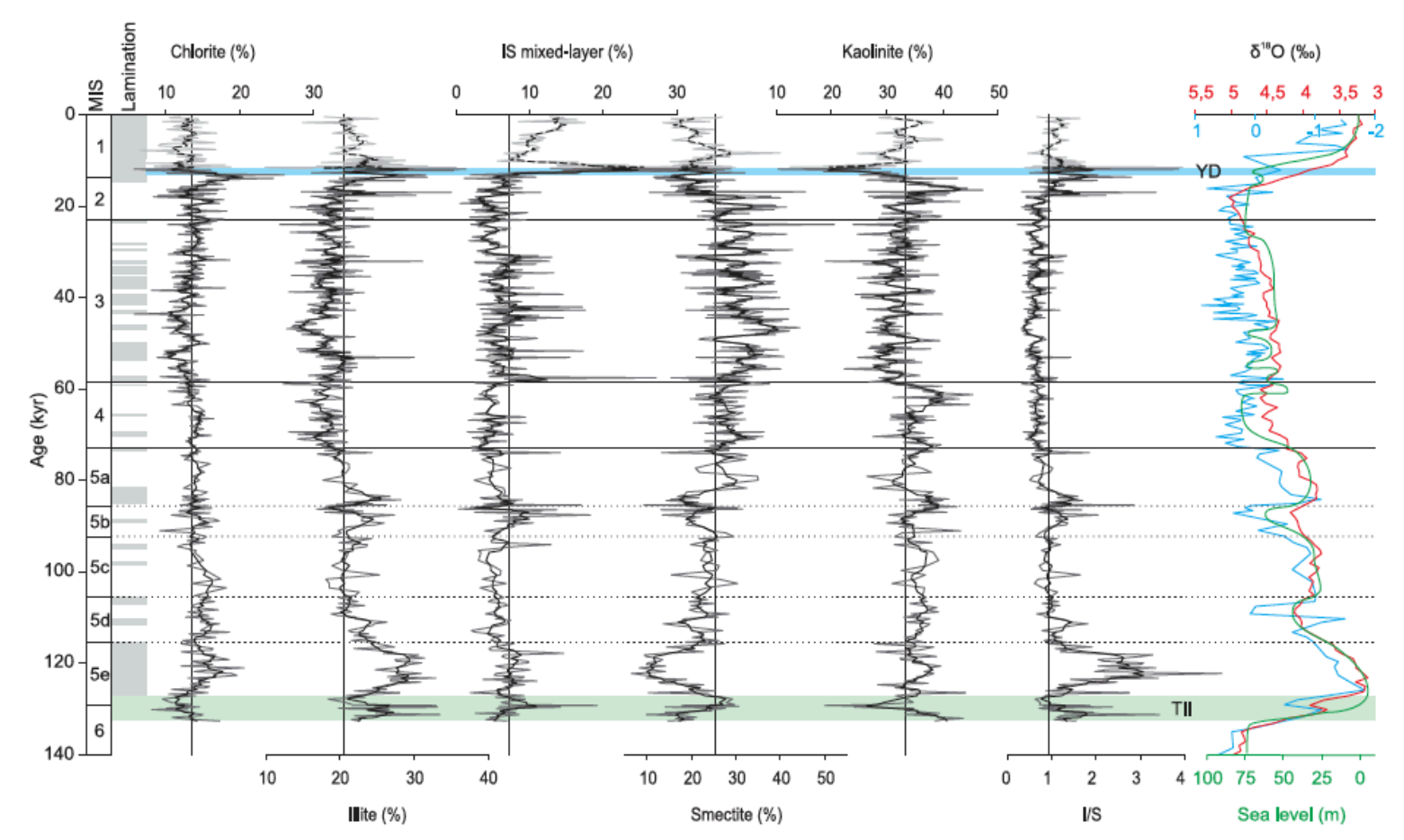

Fig. 2. Clay mineral variations in the sediments of the Cariaco Basin and illite/smectite ratio (I/S).

795 Black curves correspond to 5 points running mean. The vertical line indicates the average value. Light 796 gray curve: MD03-2625; dark gray curve: ODP 1002 hole. Intervals of sediment lamination are 797 indicated on the left. Benthic $\delta^{18} \mathrm{O}$ values (red curve) from Lisiecki and Raymo (2005). Planktonic 798 values (blue curve) modified from Drenzek (2007). Gulf of Cariaco sea level variations (green curve) 799 modified from Van Daele et al. (2011). YD: Younger Dryas; TII: Termination II. (For interpretation of 800 the references to colour in this figure legend, the reader is referred to the web version of this article.) 


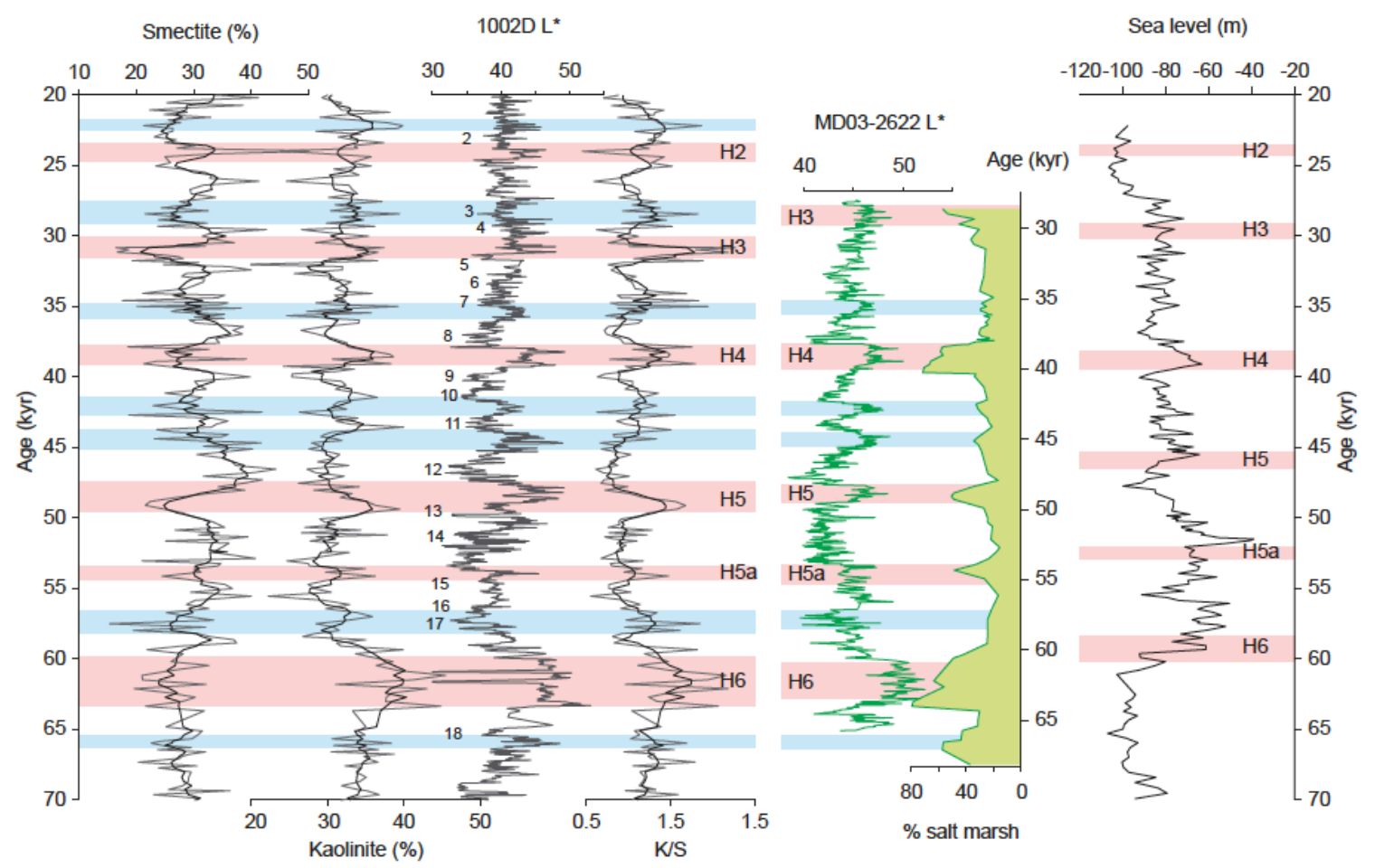

804 Fig. 3. Detailed variations of the smectite and kaolinite contents and the kaolinite/smectite ratio (K/S) 805 for the 20-70 ka interval. Black curves correspond to 5 points running mean. Sediment reflectance 806 (L*) for ODP 1002 D hole modified from Shipboard Scientific Party (1997). These data are compared 807 to the record of salt marsh pollens and sediment reflectance in core MD03-2622 from the Cariaco 808 Basin (González and Dupont, 2009), and detailed sea level variations in the Red Sea (Siddall et al., 809 2003). Notice that different age models were used for the three records. Numbers of 810 Dansgaard/Oeschger stadials are indicated on the left side of the 1002D reflectance curve (Peterson et 811 al., 2000a, 2000b). Levels in pink indicate Heinrich-like events. Levels in blue underline the good 812 consistency in the clay mineral and palynological records. (For interpretation of the references to colour in this figure legend, the reader is referred to the web version of this article.) 


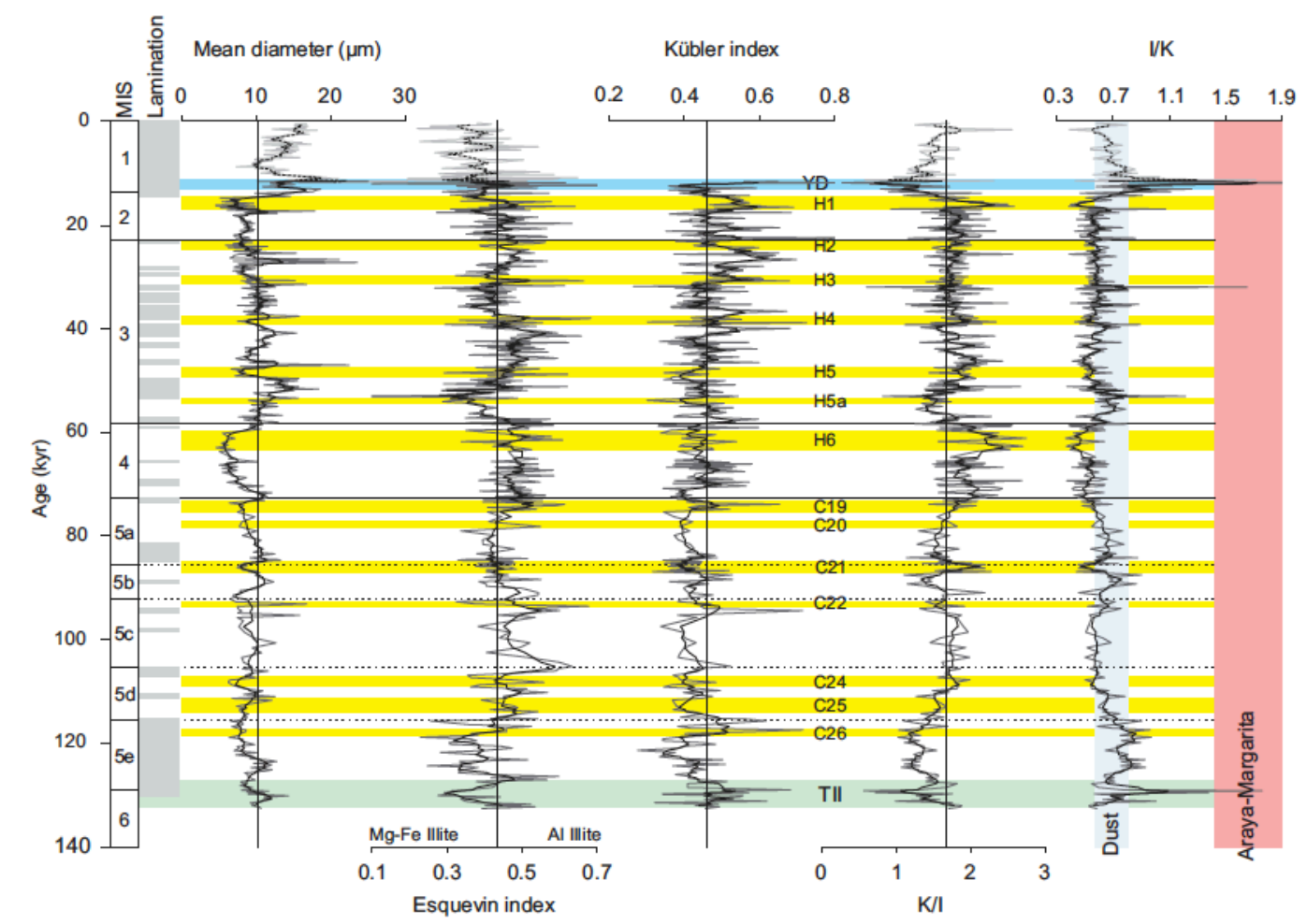

815 Fig. 4. Variations of the decarbonated sediment mean grain size, Esquevin index, Kübler index, 816 kaolinite/illite ratio $(\mathrm{K} / \mathrm{I})$ and illite/kaolinite ratio $(\mathrm{I} / \mathrm{K})$ in the sediments of the Cariaco Basin. Black 817 curves correspond to 5 points running mean. Light gray curve: MD03-2625; dark gray curve: ODP 8181002 hole. Vertical blue band: range of values of the $\mathrm{I} / \mathrm{K}$ ratio in aerosols collected in Senegal 819 (Skonieczny et al., 2013). Vertical pink band: range of values in the platform sediments from the 820 Araya-Margarita sector (Bout-Roumazeilles et al., 2013). Intervals of sediment lamination are 821 indicated on the left. Yellow horizontal bands indicate Heinrich-like events and cold stadials. YD: 822 Younger Dryas; TII: Termination II. (For interpretation of the references to colour in this figure 823 legend, the reader is referred to the web version of this article.) 

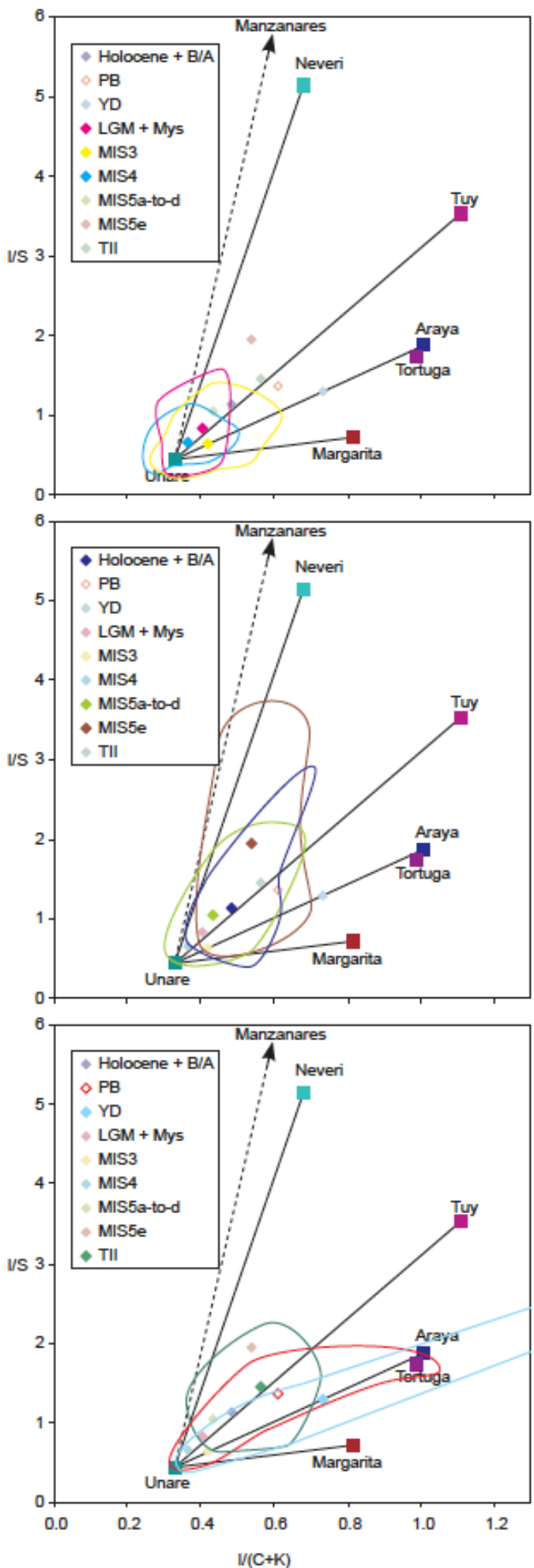

825 Fig. 5. Binary diagram illite/smectite ratio (I/S) versus illite/(chlorite + kaolinite) ratio $(\mathrm{I} /(\mathrm{C}+\mathrm{K}))$ 826 showing the area of distribution and average values of Cariaco Basin sediments from different 827 intervals compared to the average values of the different detrital sources around the basin (Bout828 Roumazeilles et al., 2013). Areas of distribution of different time intervals are highlighted in the 829 different panels for clarity. B/A: Bølling- Allerød; PB: Preboreal; YD: Younger Dryas; LGM - Mys:

830 Last Glacial Maximum to "Mystery interval" (26.5e14.6 ka). MIS: marine isotopic stage. 

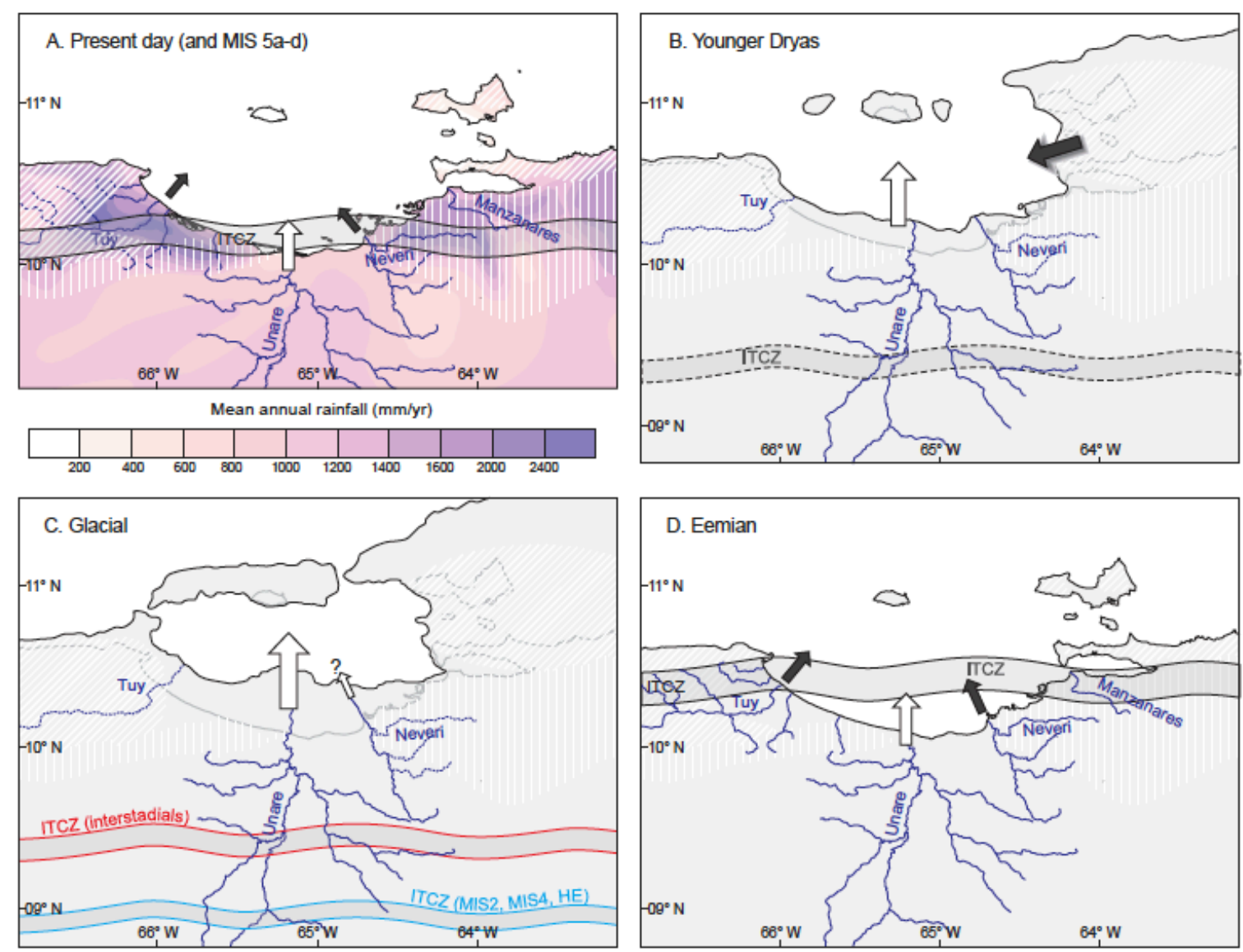

$\square$ Metamorphic rocks (Coastal range) $\square$ Deformed Mesozoic and Cenozoic sedimentary rocks (Interior range)

832 Fig. 6. Simplified geological map of North Venezuela (modified from Hackley et al., 2006) and

833 schematic diagrams comparing the sources and transport of clay minerals to the Cariaco Basin and

834 position of the summer ITCZ for different time intervals. A. Present-day geography and pluviosity 835 map (from Goldbrunner, 1984), schematic position of summer ITCZ for the present and MIS5a-to-d.

836 B. Younger Dryas. The position of summer ITCZ is uncertain. The shaded arrow indicates eolian

837 contribution. C. Last Glacial Maximum geography and schematic position of the ITCZ during 838 Heinrich events, MIS2 and MIS4 (blue) and during interstadials (red). D. Eemian. White arrows 839 represent smectite-rich sediments. Dark gray arrows illite-rich sediments. The size of the arrows 840 represents the respective contribution to the detrital flux. The width of the ITCZ band increases with 841 seasonality. (For interpretation of the references to colour in this figure legend, the reader is referred to 842 the web version of this article.) 
844 Table 1

845 Average clay mineral content and ratios of the Cariaco sediments for different time intervals.

\begin{tabular}{|c|c|c|c|c|c|c|c|c|}
\hline & Chlorite\% & Illite \% & $15 \%$ & Smectite \% & Kaolinite \% & $1 / 5$ & $1 /(C+K)$ & $\mathrm{K} / \mathrm{S}$ \\
\hline Holocene + B/A & 13.9 & 22.2 & 10,3 & 21.2 & 32.3 & 1.14 & 0.49 & 1.65 \\
\hline Preboreal $^{2}$ & 12.5 & 23.4 & 17.8 & 19.4 & 26.9 & 1.36 & 0.61 & 1.45 \\
\hline Younger Dryas & 12.2 & 23.2 & 19.4 & 21,4 & 23.8 & 1.29 & 0.73 & 1.19 \\
\hline LGM + Mys & 14.1 & 19.4 & 5.0 & 26.9 & 34.6 & 0.82 & 0.40 & 1.44 \\
\hline MIS3 & 13.0 & 18.4 & 6.4 & 30.7 & 31.5 & 0.64 & 0.42 & 1.09 \\
\hline MIS4 & 13.8 & 17.9 & 4.8 & 28.1 & 35.4 & 0.66 & 0.37 & 1.31 \\
\hline MIS5a-to-d & 14.3 & 21.6 & 5.8 & 22.5 & 35.7 & 1.04 & 0.43 & 1.69 \\
\hline MIS5e & 14.7 & 26.5 & 7.3 & 16.7 & 34.8 & 1.94 & 0.54 & 2.51 \\
\hline TII & 12.8 & 25.4 & 7.5 & 19.9 & 34.4 & 1.44 & 0.56 & 1.89 \\
\hline
\end{tabular}

846

b Last Glacial Maximum and "Mystery interval": from 26.5 to 14.6 ka.

848

849 Table 2

850 Average contribution (\%) of the Tuy, Unare and Neveri Rivers as determined from a simple mixing 851 model using Fig. 5.

\begin{tabular}{lccl}
\hline & Tuy & Neveri & Unare \\
\hline Holocene + B/A & 19 & 2 & 79 \\
LGM + Mys & 8 & 4 & 88 \\
MIS4 & 4 & 2 & 94 \\
MIS5ad & 11 & 6 & 83 \\
MIS5a & 12 & 5 & 83 \\
MIS5b & 12 & 5 & 83 \\
MIS5c & 11 & 3 & 86 \\
MIS5d & 10 & 7 & 83 \\
MIS5e & 18 & 20 & 62 \\
TII & 26 & 3 & 71 \\
\hline
\end{tabular}

852 